\title{
Comparison of the Sulforhodamine B Protein and Tetrazolium (MTT) Assays for in vitro Chemosensitivity Testing
}

\author{
Yvonne P. Keepers, Paulo E. Pizao, Godefridus J. Peters, \\ Jannette van Ark-Otte, Benjamin Winograd and Herbert M. Pinedo
}

The sulforhodamine B (SRB) protein stain assay was compared with the tetrazolium (MTT) colorimetric assay for in vitro chemosensitivity testing of various human tumour cell lines. The SRB assay provided a better linearity with cell number and a higher sensitivity, and its staining was not cell-line dependent. In contrast to the MTT assay, the SRB assay stained recently lysed cells. Cell debris, however, was not stained by SRB and therefore the drug sensitivity data were not affected.

Eurf Cancer, Vol. 27, No. 7, pp. 897-900, 1991

\section{INTRODUCTION}

SEVERAL RAPID colorimetric assays have been described for in vitro chemosensitivity testing of tumour cell-lines. In recent years, the tetrazolium (MTT) assay has been the most widely used. Several modifications of the original method [1] have been described [2-5]; however, it still has a few disadvantages. For instance, the MTT assay is not linear with cell number at high cell densities $[6,7]$, cell-lines differ in their ability to reduce the dye $[3,5,8]$, and under a number of conditions the assay has a large intra-assay and interassay variation [9].

Recently, the US National Cancer Institute (NCI) described the use of the sulforhodamine $\mathrm{B}(\mathrm{SRB})$ protein stain for in vitro chemosensitivity testing $[10,11]$. The SRB assay appeared to be more sensitive than the MTT assay, with a better linearity with cell number and higher reproducibility. In our search for major variables of in vitro drug screening we needed a sensitive, reproducible and rapid evaluation assay. The MTT assay did not fulfil all our requirements.

Here, we describe a comparison of the SRB assay with the MTT assay, which was performed in two human tumour cell lines, HT29 derived from a colorectal cancer and 11B derived from squamous cell carcinoma of the head and neck. A panel of drugs with different mechanisms of action was employed: two conventional drugs, doxorubicin and cisplatin, and four experimental drugs, which might interfere at different targets of cellular metabolism-brequinar sodium, an antimitochondrial drug [12]; ethyldeshydroxysparsomycin, a protein synthesis inhibitor [13]; miltefosine, an etherlipid, which is postulated to act on the cell membrane [14]; and the indoloquinone EO9, a bioreductive alkylating agent [15]. Several variables have been studied: sensitivity, colorimetric linearity with cell number and the possible interference of protein derived from dead cells on absorbance measurements.

Correspondence to G.J. Peters.

Y.P. Keepers, P.E. Pizao, G.J. Peters, J. van Ark-Otte and H.M. Pinedo are at the Department of Oncology, Free University Hospital, PO Box 7057, 1007 MB Amsterdam, The Netherlands; B. Winograd was at the EORTC New Drug Development Office, Free University Hospital, Amsterdam and is now at the Bristol-Myers Squibb Pharmaceutical Research Institute, Brussels, Belgium.

Revised 18 Mar. 1991; accepted 9 Apr. 1991.

\section{MATERIALS AND METHODS}

Cell-lines and culture

The human colorectal cell-line HT29 was obtained from the American Type Culture Collection (ATCC) panel and the squamous cell carcinoma cell line UM-SCC-11B (11B) from Dr T. Carey (University of Michigan, USA). Cell-lines were maintained at $37^{\circ} \mathrm{C}$ in $5 \% \mathrm{CO}_{2}$ as subconfluent monolayers in $80 \mathrm{~cm}^{2}$ culture flasks (Nunclon) and were subcultured once or twice weekly in Dulbecco's modification of Eagle's medium (Flow) supplemented with 5\% heat-inactivated fetal calf serum (FCS) (Gibco) and $1 \mathrm{mmol} / \mathrm{l} \mathrm{L}$-glutamine. During experiments, $50 \mu \mathrm{g} / \mathrm{ml}$ gentamicin was added to the culture medium. Passage levels were in the range of 5-20 after receipt of the lines from the originator.

\section{MTT assay}

We used a modification of the microculture tetrazolium assay [16]. Briefly, cells were harvested from exponential phase cultures by trypsinisation, counted and plated in 96-well flatbottomed microtitre plates (Greiner Labortechnik, Solingen, Germany) (100 $\mu$ l cell suspension per well). Optimal seeding densities for each cell line were determined to assure exponential growth during a 4-day assay, which was equivalent to absorbance readings not exceeding a value of 1.8 . Experiments were in triplicate. Following plating and a $24 \mathrm{~h}$ recovery to allow cells to resume exponential growth, $100 \mu \mathrm{l}$ culture medium or culture medium containing drug was added to the wells. $72 \mathrm{~h}$ after drug addition, $20 \mu \mathrm{l}$ MTT (final concentration, $0.5 \mathrm{mg} / \mathrm{ml}$ ) was added to the wells. After $2 \mathrm{~h}$ at $37^{\circ} \mathrm{C}$, the medium was removed and the formed formazan cristals were dissolved with $150 \mu \mathrm{l}$ dimethylsulphoxide containing $0.5 \%$ FCS. The optical density (OD) was measured at $540 \mathrm{~nm}$ using a Titertek microplate reader (Multiskan MCC/340, Flow).

\section{$S R B$ assay}

The SRB assay was performed essentially according to the method of Skehan et al. [10]. The method of plating and incubation was identical to the MTT assay till the end of the incubation. The cells were fixed by means of protein precipitation with $50 \%$ trichloroacetic acid at $4^{\circ} \mathrm{C}(50 \mu \mathrm{l} /$ well, final concentration $10 \%$ ) for $1 \mathrm{~h}$. After five washings with tap water, the cells were stained for at least $15 \mathrm{~min}$ with $0.4 \% \mathrm{SRB}$ 


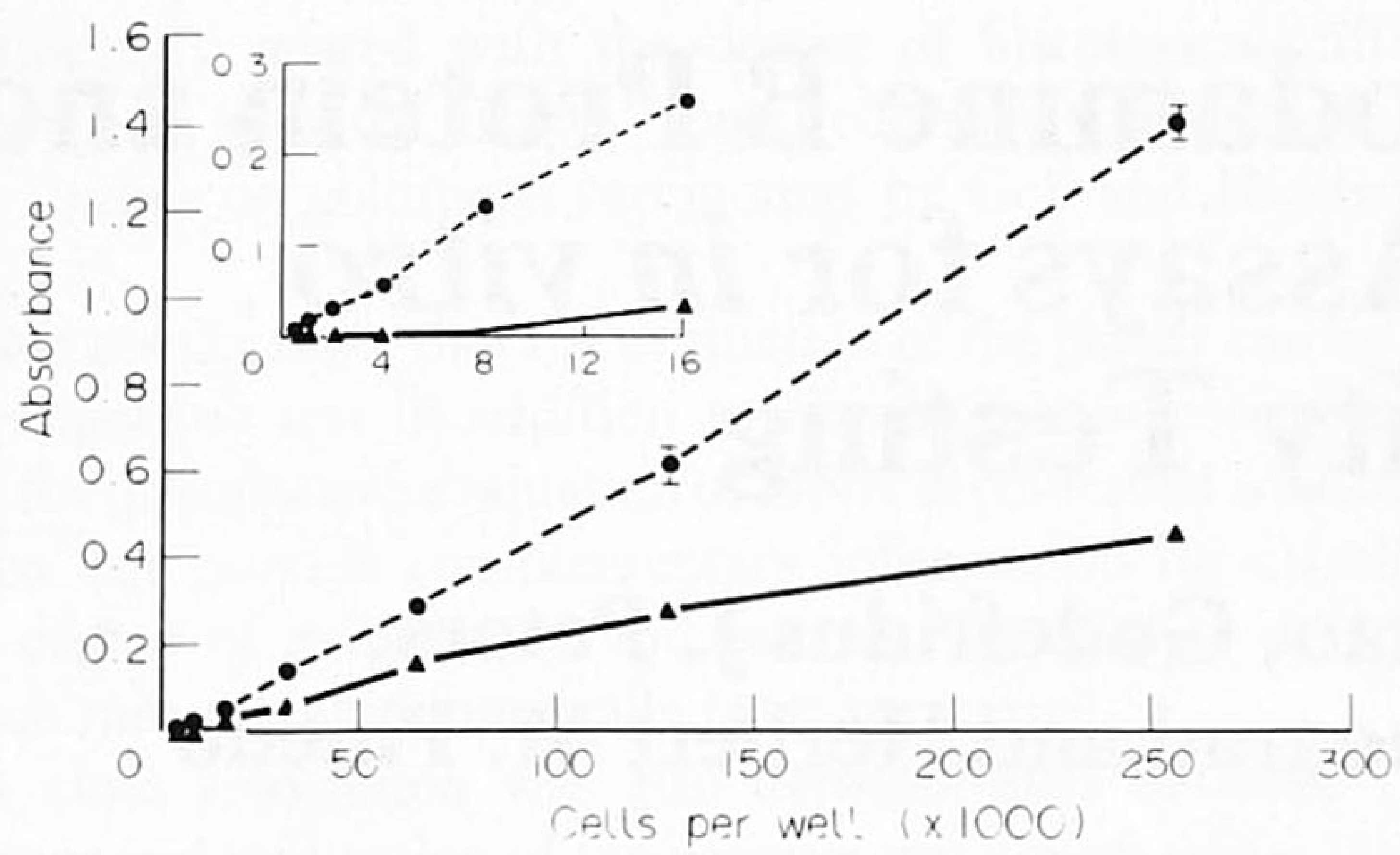

Fig. 1. Relation between plated cell number and absorbance in the MTT $(\triangle)$ and SRB $(O)$ assays. 11B cells were plated at the indicated cell densities and allowed to attach for $3 \mathrm{~h}$. MTT was read at $540 \mathrm{~nm}$, SRB at $510 \mathrm{~nm}$. Insert shows OD for both assays at $540 \mathrm{~nm}$ at low cell densities. Each point represents mean and S.D. of 3 replicates (if not indicated, error bar was within size of symbol).

dissolved in $1 \%$ acetic acid ( $50 \mu \mathrm{l} /$ well $)$ and subsequently washed four times with $1 \%$ acetic acid to remove unbound stain. The plates were air-dried and bound protein stain was solubilised with $150 \mu \mathrm{l} 10 \mathrm{mmol} / \mathrm{l}$ unbuffered Tris base [tris(hydroxymethyl)aminomethane]. The optical density was read at 540 or $510 \mathrm{~nm}$.

\section{Complement mediated lysis}

HT29 cells (6000/well) were plated and cultured for 4 days. Cells were then incubated for $1 \mathrm{~h}$ at room temperature with an anti-heavy chain monoclonal antibody (B1.23.2) [23] prior to the addition of different dilutions of rabbit complement (Bioscope Foundation, Leiden) enabling different degrees of cell lysis. The MTT and SRB assays were performed immediately following lysis and after $24 \mathrm{~h}$.

\section{Data handling}

Microplate absorbance was read on the Multiskan MCC/340 interfaced with an Olivetti personal computer. Data were collected on floppy disk using Titersoft EIA software version 2.0A (Flow). Subsequent data analysis was performed with Symphony 1.2 (Lotus).

\section{Drugs}

Doxorubicin $\mathrm{HCl}$ (Farmitalia Carlo Erba) was stored as a $3.45 \mathrm{mmol} / \mathrm{l}$ stock solution in $0.9 \% \mathrm{NaCl}$. Cisplatin (Bristol Myers) was stored as a $3.3 \mathrm{mmol} / \mathrm{l}$ stock solution in $0.9 \%$ $\mathrm{NaCl}$. Brequinar sodium (DuP 785) (DuPont) was stored as a $10 \mathrm{mmol} / \mathrm{l}$ stock solution in phosphate-buffered saline (PBS). Miltefosine was a gift of Dr P. Hilgard (Asta Pharma, Bielefeld, Germany). It was stored as a $0.024 \mathrm{~mol} / \mathrm{l}$ stock solution in PBS. EO9 (NDDO, Free University, Amsterdam) was stored as a $0.04 \mathrm{~mol} / \mathrm{l}$ stock solution in absolute ethanol. Ethyldeshydroxysparsomycine was a gift of Dr H. Hofs (Nijmegen) and was stored as a $5 \mathrm{mg} / \mathrm{ml}$ stock solution in PBS. All stock solutions were stored at $-20^{\circ} \mathrm{C}$, except for cisplatin which was stored in the dark at room temperature. Drugs were thawed and diluted in culture medium prior to use.

\section{RESULTS}

To determine the sensitivity and the relation between cell number and OD in the MTT and SRB assays, 11B cells were plated at a large range of seeding densities. After a 3-h incubation to allow cell attachment, the MTT and SRB assays were performed (Fig. 1). In the SRB assay, there was a linear relation

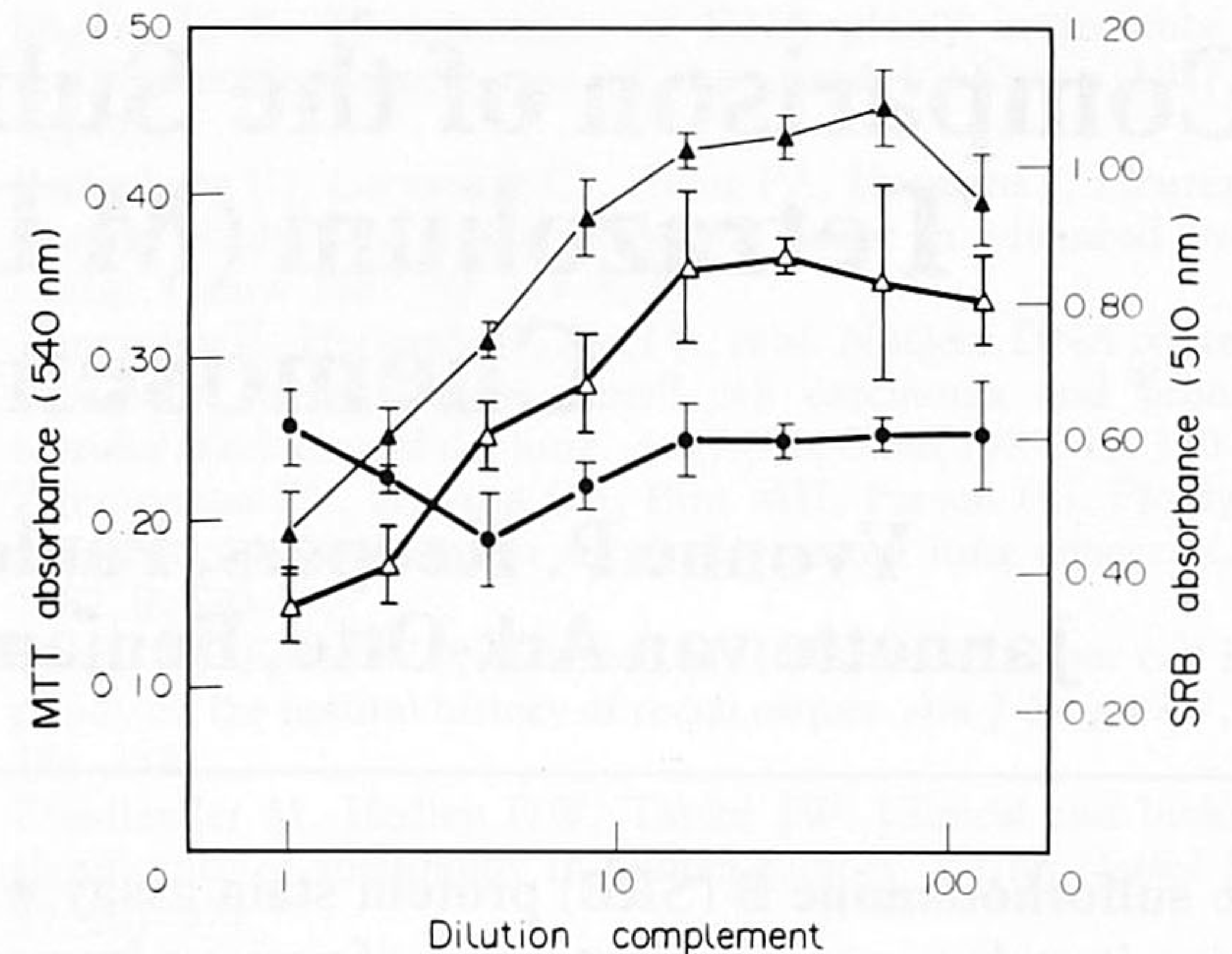

Fig. 2. Effect of cell lysis on MTT and SRB assays. HT29 cells (6000/well) were cultured for 4 days. MTT $(\triangle)$ and SRB assays $(\triangle$, -) were performed immediately $(\Theta)$ and $24 \mathrm{~h}(\Delta)$ after complement lysis. Each point represents mean and S.D. of 3 replicates.

between plated cell number and OD at $510 \mathrm{~nm}$, which is a suboptimal wavelength (the OD at $540 \mathrm{~nm}$, the optimal wavelength, is 5 times the OD at $510 \mathrm{~nm}$ in the linear range). The MTT assay did not provide a linear relation with cell number, at least not at higher cell densities. At the low cell densities $(<16000$ cells/well $)$ no significant difference with the blanks could be observed in the MTT assay, but when using the optimal wavelength for the SRB assay 2000 cells/well could be measured reliably (inset Fig. 1).

The MTT assay can be used to assess cytotoxicity because only metabolically active cells can reduce the salt to its formazan product; therefore, dead cells do not interfere with MTT absorbance levels [1]. We considered it theoretically possible that, as a protein stain, the SRB could overestimate actual cell numbers by staining protein fractions corresponding to cell culture debris. Increasing complement dilutions would produce less cell lysis, and, as expected, this produced proportionally higher MTT measurements independently of when the assay was performed (Fig. 2; data for 24 h [not shown] were identical). The SRB absorbance readings, performed immediately after lysis, were not proportional to the degree of cell lysis and OD values corresponding to the highest and lowest complement dilution were almost identical. However, the same absorbance profile was observed with both the MTT and SRB assays performed $24 \mathrm{~h}$ after cell lysis.

Table 1. Chemosensitivity (expressed as $I C_{50}$ ) of HT29 and $11 B$ cells assessed by the MTT and SRB assays

\begin{tabular}{lccccc}
\hline & \multicolumn{2}{c}{ HT29 } & & \multicolumn{2}{c}{$11 \mathrm{~B}$} \\
\cline { 2 - 3 } \cline { 5 - 6 } Drug & MTT & SRB & & MTT & SRB \\
\hline Doxorubicin & 0.3 & 0.3 & & 0.1 & 0.2 \\
Cisplatin & 30 & 20 & & 5 & 6 \\
Brequinar & 0.5 & 2 & & 0.5 & 0.1 \\
EdSm* & 0.6 & 1 & & 0.4 & 0.6 \\
Miltefosine & 3 & 6 & & 30 & 30 \\
EO9 & 0.03 & 0.04 & & 0.02 & 0.03 \\
\hline
\end{tabular}

$\mathrm{IC}_{50}$ in $\mathrm{mmol} / \mathrm{l}$, except ${ }^{*} \mathrm{IC}_{50}$ in $\mu \mathrm{g} / \mathrm{ml}$. Plating density HT29: 6000 cells/well, 11B: 12000 cells/well, $72 \mathrm{~h}$ drug exposure. $\mathrm{EdSm}=$ ethyldeshydroxysparsomycin. 


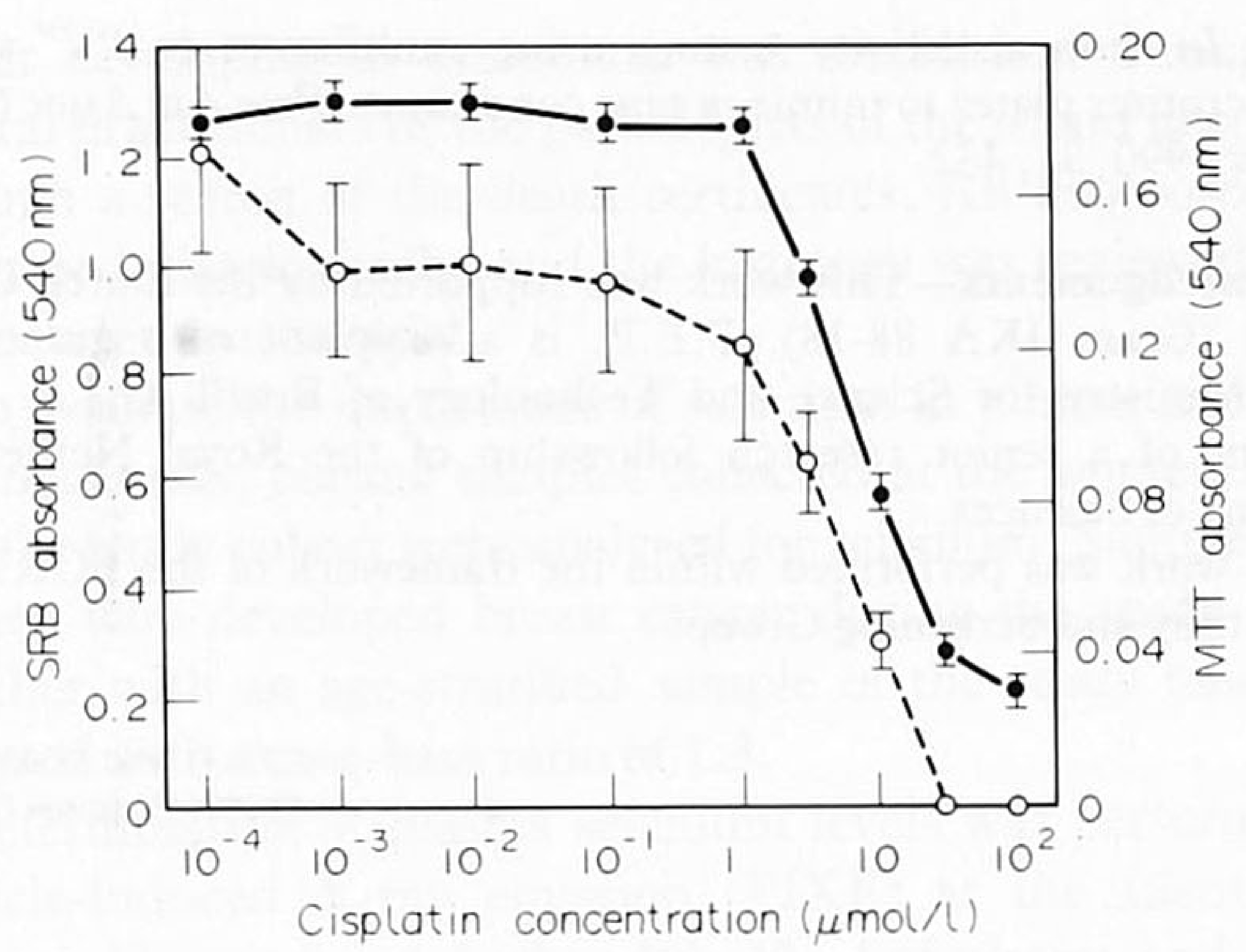

Fig. 3. Dose-response curves for cisplatin-treated 11B cells (12 000/well). Drug sensitivity was determined $72 \mathrm{~h}$ after drug addition. $\bigcirc$, MTT assay;, SRB assay. Each point represents mean and S.D. of 3 replicates.

To validate the SRB assay, we studied it in parallel with the MTT using HT29 and 11B cells and selected a number of drugs with different mechanisms of action (Table 1). $\mathrm{IC}_{50}$ values (drug concentration resulting in $50 \%$ growth inhibition) calculated from dose-response curves determined with the SRB assay did not differ from $\mathrm{IC}_{50}$ values determined with the MTT assay. Figure 3 shows the dose-response curves of one experiment. The OD values of the SRB assay were much higher and the variation was much lower than in the MTT assay.

\section{DISCUSSION}

The SRB assay provided a better linearity with cell number than the MTT assay. Even at a suboptimal wavelength $(510 \mathrm{~nm})$, the absorbance values in the SRB assay were generally 2-3 times higher, depending on the cell-line tested. The SRB assay is, because of its large linearity range, suitable to study chemosensitivity of subconfluent monolayers and multilayer cell clusters containing large amounts of cells $[10,18]$. In contrast to the MTT assay, SRB staining is stable and plates can be stored for several weeks up to several months. In addition, the protein assay can be interrupted at several steps during the protocol [10].

The results of the complement lysis test show that SRB stained recently lysed cells in contrast to MTT, which can only be reduced by intact cells. However, $24 \mathrm{~h}$ after lysis, the SRB assay showed the same profile as the MTT assay, which means that cell debris was not stained then by SRB. Therefore, it is not likely that under normal growth conditions the SRB assay will overestimate the surviving fraction of cells in the chemosensitivity test due to cell debris. Our data indicate that, when chemosensitivity data are limited to $\mathrm{IC}_{50}$ values, the MTT and SRB assay give comparable results. Even when drugs were tested which could theoretically cause a difference, e.g. an antimitochondrial drug (brequinar) or a protein synthesis inhibitor (ethyldeshydroxysparsomycin), no discrepancy in $\mathrm{IC}_{50}$ was found. Rubinstein $e t$ al. [16] compared the chemosensitivity of 38 cell-lines to 197 compounds. They found a discrepancy between the MTT and SRB assays for a small subset (12\%) of compounds, but could not identify either of the assays as being responsible for the discrepancy. The phenomenon was restricted to the portion of the dose-response curve below $10 \%$ of relative growth and, therefore did not influence the $\mathrm{IC}_{50}$ values. According to our results, this could be explained by staining of dead cells by SRB.
The SRB assay not only provides a higher sensitivity but also a lower variation between cell-lines. $11 \mathrm{~B}$ cells have a relatively poor capacity to reduce MTT, and show high OD values in the SRB assay. This underlines the advantage of the SRB assay, which does not depend on enzymatical activity but on protein content. The SRB assay has now been used as a chemosensitivity test in our laboratory with more than 25 lines with a different histological origin (squamous cell carcinoma and colon, ovarian, breast and prostate cancer, fibroblasts and leukaemia, bone marrow cells) from man, rat and mouse. The variation in OD between these cell-lines is less than in a comparable panel of cell-lines tested with the MTT assay (data not shown).

In conclusion, the SRB and MTT assays gave comparable results in drug sensitivity testing of human tumour cell-lines when used as an end point assay. For the study of growth kinetics in the absence and presence of drug, the SRB assay is more suitable because of the higher sensitivity and better linearity with cell number. Our data obtained with the complement lysis test demonstrates that cell debris does not interfere significantly in chemosensitivity testing. In general, the SRB assay represents a better method of assessing in vitro chemosensitivity.

1. Mosmann T. Rapid colorimetric assay for cellular growth and survival: application to proliferation and cytotoxicity assays. $\mathcal{F}$ Immunol Meth 1983, 65, 55-63.

2. Cole SPC. Rapid chemosensitivity testing of human lung tumor cells using the MTT assay. Cancer Chemother Pharmacol 1986, 17, 259-263.

3. Denizot F, Lang R. Rapid colorimetric assay for cell growth and survival. Modifications to the tetrazolium dye procedure giving improved sensitivity and reliability. F Immunol Meth 1986, 89, 271-277.

4. Twentyman PR, Luscombe M. A study of some variables in a tetrazolium dye (MTT) based assay for cell growth and chemosensitivity. Br f Cancer 1987, 56, 279-285.

5. Scuidiero DA, Shoemaker RH, Paull KD, et al. Evaluation of a soluble tetrazolium/formazan assay for cell growth and drug sensitivity in culture using human and other tumor cell lines. Cancer Res 1988, 48, 4827-4833.

6. Ruben RL, Neubauer RH. Semiautomated colorimetric assay for in vitro screening of anticancer compounds. Cancer Treat Rep 1987, 71, 1141-1149.

7. Plumb JA, Milroy R, Kaye SB. Effects of the $\mathrm{pH}$ dependence of 3(4,5-dimethylthiazol-2-yl)-2,5-diphenyltetrazolium bromide formazan absorption on chemosensitivity determined by a novel tetrazolium-based assay. Cancer Res 1989, 49, 4435-4440.

8. Ford CHJ, Richardson VJ, Tsaltas G. Comparison of tetrazolium colorimetric and $\left[{ }^{3} \mathrm{H}\right]$-uridine assays for in vitro chemosensitivity testing. Cancer Chemother Pharmacol 1989, 24, 295-301.

9. Park JG, Kramer BS, Steinberg SM, et al. Chemosensitivity testing of human colorectal carcinoma cell lines using a tetrazolium based colorimetric assay. Cancer Res 1987, 47, 5875-5879.

10. Skehan $\mathrm{P}$, Storeng $\mathrm{P}$, Scudiero $\mathrm{D}$, et al. New colorimetric cytotoxicity assay for anticancer-drug screening. $\mathcal{F}$ Natl Cancer Inst 1990, 82, 1107-1112.

11. Rubenstein LV, Shoemaker RH, Paull KD, et al. Comparison of in vitro anticancer-drug screening data generated with a tetrazolium assay versus a protein assay against a diverse panel of human tumor cell lines. 7 Natl Cancer Inst 1990, 82, 1113-1118.

12. Peters GJ, Sharma SL, Laurensse E, Pinedo HM. Inhibition of pyrimidine de novo synthesis by DUP-785 (NSC 368390). Invest New Drugs 1987, 5, 235-244.

13. Hofs HP, Wagener DJTh, De Valk-Bakker V, Biermans FCM, Ottenheijm HCJ. Enhancement of cisplatin antitumor activity by ethyldeshydroxysparsomycin. In: Metal Ions in Biology and Medicine. Paris, John Libbey Eurotext, 1990, 363-365.

14. Eibl H, Unger C, Fieer EAM, et al. Hexadecylphosphocholine, a new antineoplastic agent. Cytotoxic properties in leukaemia cells. $\mathcal{F}$ Cancer Res Clin Oncol 1986, 111, 24. 
15. Roed H, Aabo K, Vindelov L, Spang-Thomsen M, Christensen IBJ, Hansen $\mathrm{HH}$. In vitro and in vivo evaluation of the indoloquinone EO-9 (NSC 382 459) against human small cell carcinoma of the lung. Eur 7 Cancer Clin OA col 1989, 25, 1197-1201.

16. Alley MC, Scudiero DA, Monks A, et al. Feasibility of drug screening with panels of tumor cell lines using a microculture tetrazolium assay. Cancer Res 1988, 48, 589-601.

17. Rebai N, Malissen B. Structural and genetic analyses of HLA class I molecules using monoclonal xenoantibodies. Tissue Antigens 1983, 22, 107-117.

18. Pizao PE, Leyva A, Keepers Y, Peters GJ, Pinedo HM, Winograd
B. In vitro sensitivity testing using multilayers in "V"-shaped microtiter plates to mimic in vivo conditions. Proc Am Assoc Cancer Res 1990, 31, 432.

Acknowledgements-This work was supported by the Dutch Cancer Society (Grant IKA 88-18). P.E.P. is a recipient of a grant from $\mathrm{CNPq} /$ Ministry for Science and Technology of Brazil. G.J.P. is the recipient of a senior research fellowship of the Royal Netherlands Academy of Sciences.

This work was performed within the framework of the EORTC-In Vitro Study and Screening Group.

\title{
Selenium in Human Mammary Carcinogenesis: a Case-cohort Study
}

\author{
Kim Overvad, Dennis Y. Wang, Jørn Olsen, Diane S. Allen, Eivind B. Thorling, \\ Richard D. Bulbrook and John L. Hayward
}

In a prospective study conducted on the island of Guernsey a cohort of 5162 ostensibly healthy women was enrolled between 1967 and 1976. Blood samples were drawn from each participant, who also completed a questionnaire, which provided information on established risk indicators in human mammary carcinogenesis. Plasma selenium levels were measured in 46 breast cancer cases diagnosed a mean of 11 (S.D. 4) years after entry into the study cohort and in an age-stratified sample of 138 women drawn from the study base. Plasma selenium level in the cases was $109(28) \mu \mathrm{g} / \mathrm{l}$ and in the base sample $103(22) \mu \mathrm{g} / 1$ (95\% confidence interval for the overall difference, -2 to $14 \mu \mathrm{g} / 1$ ). The adjusted relative risk of developing breast cancer in the different quartiles of the selenium distribution was $0.80,0.79,0.72$ and 1.00 , respectively. Thus, in the present study selenium was not a strong indicator of human breast cancer risk.

Eur $\mathcal{F}$ Cancer, Vol. 27, No. 7, pp. 900-902, 1991

\section{INTRODUCTION}

THE EPIDEMIOLOGICAL evidence pertaining to a relationship between selenium and human mammary carcinogenesis is confused. Studies on aggregated data revealed decreasing human breast cancer mortality rates at increasing levels of selenium exposure $[1,2]$. Of three case-referent studies, two reported relatively low levels of blood selenium in the cancer patients [ 3 , 4], while in the remaining study mean selenium levels among cases and referents were comparable, although the selenium distributions indicated a positive association between selenium levels and cancer risk [5].

Several historical prospective studies have examined the relation between measures of selenium exposure and cancer risk. One study on blood selenium levels indicated a positive association between selenium levels and breast cancer risk [6],

Correspondence to K. Overvad.

$\mathrm{K}$. Overvad and J. Olsen are at the Institute of Social Medicine, University of Aarhus, Høegh-Guldbergs Gade 8, DK-8000 Aarhus C, Denmark; D.Y. Wang, D.S. Allen and R.D. Bulbrook are at the Department of Clinical Endocrinology, Imperial Cancer Research Fund, London, U.K.; E.B. Thorling is at the Danish Cancer Society, Department of Nutrition and Cancer, Aarhus Municipal Hospital, Aarhus C, Denmark; and J.L. Hayward is at the Breast Unit, Guy's Hospital, London, U.K.

Revised 4 Apr. 1991; accepted 9 Apr. 1991. while another study on nail selenium levels indicated no such association [7].

The present study was undertaken to examine the importance of selenium in human mammary carcinogenesis, considering breast cancer cases in which the diagnoses were made several years after collection of blood specimens to minimise the possibility of disease mediated changes in selenium levels.

\section{MATERIALS AND METHODS}

Between 1967 and 1976, a cohort of 5162 ostensibly healthy women, aged 35 years or more, was enrolled to investigate the importance of hormonal factors in human mammary carcinogenesis. The women, who lived on the island of Guernsey, had volunteered to take part in the epidemiological investigation. They were recruited by their doctors, from various women's organisations and by appeals in the local press and on the television. This cohort was derived from a population of approximately 13000 eligible women.

At entry into the study cohort, non-fasting blood samples were drawn from each participant. Heparinised plasma was prepared and stored at $-20^{\circ} \mathrm{C}$. Each woman completed a questionnaire, which provided information on the following established risk indicators in human mammary carcinogenesis: date of birth, family history of breast cancer, age at menarche, number of children, age at first baby, breast feeding, age at menopause, height and weight. A record of diagnoses of breast 